\title{
An Overview of an Acidic Uranium Mine Pit Lake (Caldas, Brazil): Composition of the Zooplankton Community and Limnochemical Aspects
}

\author{
Carla R. Ferrari ${ }^{1} \cdot$ Heliana de Azevedo ${ }^{1} \cdot$ Maria José S. Wisniewski $^{2}$. \\ Suzelei Rodgher $^{3}$ - Cláudio Vitor Roque ${ }^{1}$ - Marcos Roberto L. Nascimento ${ }^{4}$
}

Received: 13 January 2014 / Accepted: 2 March 2015/Published online: 24 March 2015

(C) Springer-Verlag Berlin Heidelberg 2015

\begin{abstract}
Water samples were collected quarterly for 1 year from the newly created Osamu Utsumi uranium mine pit lake, Brazil, which is affected by acid mine drainage (AMD). The water presented mean $\mathrm{pH}$ values of 3.8, high mean electrical conductivity values $(2391 \mu \mathrm{S} /$ $\mathrm{cm})$, manganese $(74 \mathrm{mg} / \mathrm{L})$, sulfate $(1413 \mathrm{mg} / \mathrm{L})$ and uranium $(3 \mathrm{mg} / \mathrm{L})$. The density of rotifera was significantly higher than that of cladoceran. Rotifera Keratella americana, K. cochlearis and the Cladocera Bosminopsis deitersi, Bosmina sp., are being reported for the first time in samples from a uranium pit lake with AMD. Of the species registered, the order Bdelloidea was the most important in terms of density $\left(17,500-77,778 \mathrm{ind} / \mathrm{m}^{3}\right)$, since it occurred throughout the whole sampling period. The combined effect of moderately acidic $\mathrm{pH}$ and other potential stress factors, such as high concentrations of stable and radioactive contaminants, probably influenced the zooplankton species composition in the pit lake.
\end{abstract}

Heliana de Azevedo

hazevedo@cnen.gov.br

1 Radioecology Laboratory/Poços de Caldas Laboratory, Brazilian Nuclear Energy Commission, Rodovia Poços de Caldas-Andradas Km 13, Poços de Caldas, MG 37701-970, Brazil

2 Limnology Laboratory, Biology Department, Alfenas Federal University, Rua Gabriel Monteiro da Silva 700, Alfenas, MG 37130-000, Brazil

3 Environmental Engineering Department, University Estadual Paulista, Rod. Presidente Dutra, Km 137,8,

São José dos Campos, SP 12247-004, Brazil

4 Chemical Analyzes Laboratory/Poços de Caldas Laboratory, Brazilian Nuclear Energy Commission, Rodovia Poços de Caldas-Andradas Km 13, Poços de Caldas, MG 37701-970, Brazil
Keywords Mine pit lake - Acid mine drainage . Bdelloidea

\section{Introduction}

The environmental problems caused by mining vary based on the material extracted, processing techniques used, local geography and geology and time scales involved. Although it is generally accepted that mining can negatively affect the local biota by altering the natural community structure and reducing biodiversity (Ciszewski et al. 2013; Durán et al. 2013; Holopainen et al. 2003; Lefcort et al. 2010), such areas may also support significant populations of rare or threatened fauna (Batty 2005; Moser and Weisse 2011). Pit lakes are a common legacy of modern, large-scale surface mining (Eary and Castendyk 2013) and result from the infilling of mine pits by rising groundwater and surface water from streams and rainfall after the cessation of open-cast mining (Nixdorf et al. 2005). Many pit lakes are young (only a few decades old) and the number of studies on physical, chemical, and biological processes in these artificial ecosystems is limited (Wendt-Potthoff 2013).

One environmental problem of pit lakes is acid mine drainage (AMD), which occurs when metal sulfides are exposed to atmospheric, hydrological, and biological weathering (oxygen, water, and chemoautotrophic bacteria). The reduced $\mathrm{pH}$ mobilizes some metallic elements (e.g. $\mathrm{Al}, \mathrm{Cu}, \mathrm{Mn}, \mathrm{Fe}, \mathrm{Cd}, \mathrm{Pb}, \mathrm{Zn}, \mathrm{U}$ ), depending on tailings and waste rock mineralogy (Campos et al. 2011; Luís et al. 2009; Lyew and Sheppard 1997, 2001; Sheoran and Sheoran 2006; Soucek et al. 2001). The high concentrations of dissolved metals and sulfate and the acidic $\mathrm{pH}$ adversely affect aquatic biota (Soucek et al. 2000, 2001). 
The first acidic pit lake formed as a result of uranium ore mining in Brazil is located in the elevated plateau region of the city of Poços de Caldas, Minas Gerais State, Brazil (Osamu Utsumi pit lake). This newly-created artificial lake was formed as a result of exploration of uranium deposits on the grounds of the Mineral Ore Treatment Unit of the Brazilian Nuclear Industries (UTM/INB). Complex mixtures containing uranium and other highly toxic metals can exist at a uranium ore deposit with AMD, and the effects of these on the environment have yet to be completely elucidated (Antunes et al. 2007). According to Riethmuller et al. (2001), uranium can be highly toxic to freshwater biota.

With respect to the zooplankton community in acidic pit lakes, most studies have been done in Germany, indicating the need to expand the knowledge concerning the organisms of these singular habitats outside Europe (Belyaeva and Deneke 2007, 2013; Deneke 2000; Lessmann et al. 1999; Nixdorf et al. 1998; Wollmann et al. 2000). Similarly, most studies about the differences in the sensitivity of zooplankton organisms to acidified water were carried out in Europe and North America. Therefore, the extrapolation of zooplankton sensitivity rankings to other regions, namely the tropics, is questionable (Saro et al. 2011). Moreover, little is known about zooplankton communities in newly created pit lakes (Wendt-Potthoff 2013). The present study was designed to assess the zooplankton community composition and physical and chemical characteristics of the water in an acidic uranium mining lake in a tropical region.

\section{Materials and Methods}

\section{Description of the Studied Site}

The Ore Treatment Unit of the Brazilian Nuclear Industries (Fig. 1) is located in the Poços de Caldas Plateau (Minas Gerais State, Brazil) at $1291 \mathrm{~m}$ above sea level. The area is in a tropical climatic zone, with two distinct seasons: the rainy season, between October and March, has an average temperature of $20{ }^{\circ} \mathrm{C}$, while the dry season, between April and August, has an average temperature of $14{ }^{\circ} \mathrm{C}$ (Rodgher et al. 2013). The mine area was projected to treat $2500 \mathrm{t}$ of ore/day, but mining was permanently suspended in October 1995. Currently, the environmental effects of the AMD represent an obligation and legal responsibility of UTM/ INB with respect to the site's treatment, decommissioning, and recovery. The focus of this study was the Osamu Utsumi pit lake, located on the UTM/INB grounds. The uranium found in this mining area is associated with ferrous sulfide $\left(\mathrm{FeS}_{2}\right)$, which, in the presence of water and oxygen, provides adequate conditions for AMD. This acidic effluent contains high concentrations of fluoride, sulfate, manganese, zinc, uranium, and other contaminants (Nascimento et al. 1988). Before being discharged into the environment, the AMD is treated with slaked lime and flocculating agents and then separated by decantation, with stable and radioactive metals having precipitated (Nóbrega et al. 2008). The precipitates, including the calcium diuranate formed as a result of this treatment, are returned to the pit lake, affecting the contaminant concentrations.

\section{Experimental Design}

Water samples were collected quarterly (two samplings in the rainy season and two in the dry season), for 1 year (2008-2009). The samples were collected close to the water surface of the pit lake (Fig. 1) using a vertical, $5 \mathrm{~L}$ Van Dorn flask, transferred to previously-washed plastic bottles, and stored at $4{ }^{\circ} \mathrm{C}$ until taken to the laboratory for analysis. The zooplankton community surface water was sampled using a plankton net.

\section{Physical Properties and Limnochemistry of the Water}

A WTW model $597 \mathrm{pH}$ meter $(\mathrm{GmbH}$, Weilheim, Germany) was used to measure $\mathrm{pH}$; the electrical conductivity (EC) was determined using a Digimed (São Paulo, Brazil) DM-31 conductivity meter. Fluoride concentrations were estimated using a potentiometric method with an ionselective electrode (Nascimento et al. 1988), while sulfate was determined by UV-visible spectrophotometry using ASTM methodology (1980). To determine total Fe, Mn, $\mathrm{Al}$, and $\mathrm{Zn}$ concentrations, samples were stored in polyethylene bottles and fixed with ultra-pure nitric acid to a final concentration of $0.2 \mathrm{M}$. The samples were digested as described in APHA (1995) and the concentrations were determined by inductively-coupled plasma atomic-absorption spectrometry with a Liberty RL sequential ICP-OES (Varian, USA). To analyze uranium, aliquots of the water samples were extracted with the solvent tributylphosphate, treated with a solution of the colorimetric reagent Arsenazo III, and the absorbance was measured at $650 \mathrm{~nm}$ in a UVVis spectrophotometer (Fukuma et al. 2001). Total nitrogen was determined based on the methodology described by Golterman et al. (1978), while total phosphorus was determined by the method described in APHA (1995).

\section{Zooplankton Community}

To analyze the zooplankton community, $100 \mathrm{~L}$ surface water samples were collected and subsequently filtered for Rotifera, using a net with $10 \mu \mathrm{m}$ mesh. In acid mine lakes, one should consider the size of the organisms, since the 
Fig. 1 Map of the sampling site in the Mineral Ore Treatment Unit of the Brazilian Nuclear Industries, showing the uranium mine pit lake

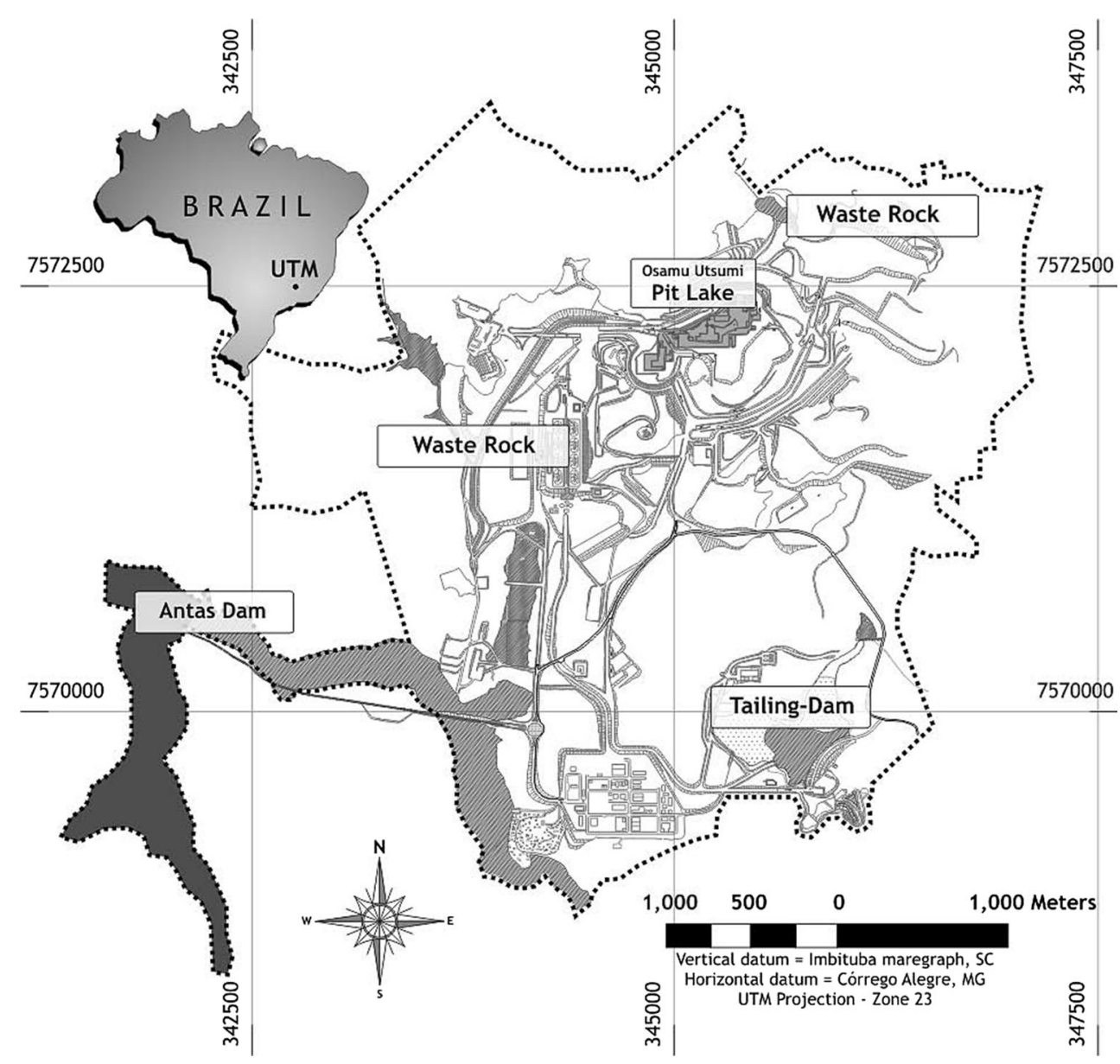

communities of these lakes are frequently dominated by small rotifers (Deneke 2000). Concomitantly, for Crustacea (Cladocera and Copepoda), $100 \mathrm{~L}$ of water were collected and filtered using a net of $60 \mu \mathrm{m}$ mesh (Woelfl and Whitton 2000). The organisms were then fixed in $4 \%$ formaldehyde (final concentration) and stored in glass flasks for subsequent identification of the main zooplankton groups (Cladocera, Copepoda, and Rotifera) under an optical microscope (Zeiss-Axioplan-2) with magnification up to $1000 \times$. Cladocera and Copepoda counts were carried out using gridded acrylic plates under a stereoscopic microscope (Zeiss-Stemi SV11), with magnification up to $66 \times$, counting sub-samples or even whole samples for rare organisms. For the Rotifera, $1 \mathrm{~mL}$ sub-samples were counted in a Sedgewick-Rafter chamber using the Zeiss optical microscope with magnification up to $1000 \times$. Specialized literature was used to identify the zooplankton (De-Melo and Hebert 1994; Elmoor-Loureiro 1997; Koste 1978; Kotov et al. 2009; Shiel and Koste 1992, 1993). The zooplankton density results were analyzed using ANOVA and Tukey's test (post hoc test) using the BioEstat 4.0 program (Ayres et al. 2005) to detect significant differences between zooplankton groups.

\section{Results}

\section{Physical Properties and Limnochemistry of the Water}

The physical and chemical parameters of the Osamu Utsumi water samples are presented in Table 1. The water had a mean $\mathrm{pH}$ of 3.8. The EC values ranged from 1976 to $2760 \mu \mathrm{S} / \mathrm{cm}$. Sulfate concentrations were elevated $(366-1832 \mathrm{mg} / \mathrm{L})$. The average concentrations of ions measured in the pit lake samples were: $\mathrm{Al}(81.9 \mathrm{mg} / \mathrm{L}), \mathrm{F}^{-}$ (55.3 mg/L), Mn (74.5 mg/L), Th (0.15 mg/L), U (2.95 mg/ $\mathrm{L})$, and $\mathrm{Zn}(15.5 \mathrm{mg} / \mathrm{L})$. The average concentrations of total Fe were $4.27 \mathrm{mg} / \mathrm{L}$, with $\mathrm{Fe}^{3+}$ presenting higher concentrations $(1.4-10.2 \mathrm{mg} / \mathrm{L})$ than $\mathrm{Fe}^{2+}(<0.15-0.6 \mathrm{mg} / \mathrm{L})$. The highest concentrations registered for total nitrogen and total phosphorus were 840 and $18 \mu \mathrm{g} / \mathrm{L}$, respectively.

\section{Zooplankton Community}

Regarding the zooplankton community, low and high species densities were recorded throughout the whole study. The average density value for the Rotifer group 
$\left(66,390 \mathrm{ind} / \mathrm{m}^{3}\right)$ was significantly higher $(P<0.05$, Tukey's test) than that of the Cladoceran group (977 ind/ $\mathrm{m}^{3}$ ). Four species belonging to the Rotifera phylum were identified (Keratella americana, $K$. cochlearis, Cephalodella sp., and Bdelloidea order), while only two species of the Cladocera group (Bosmina sp. and Bosminopsis deitersi) were registered (Table 2). For the Rotifer group, average density values of Keratella americana (143 ind $/ \mathrm{m}^{3}$ ) and $K$. cochlearis (208 ind $/ \mathrm{m}^{3}$ ) were significantly lower $(P<0.05$, Tukey's test $)$ than those for the Cephalodella sp. $\left(25,350 \mathrm{ind} / \mathrm{m}^{3}\right)$. Of the species registered in the pit lake samples, the Bdelloidea was the most important in terms of average density values $\left(39,580 \mathrm{ind} / \mathrm{m}^{3}\right)$, since it occurred throughout the whole sampling period, followed by Cephalodella sp. The Rotifera Keratella americana and $K$. cochlearis and the Cladocera Bosminopsis deitersi and Bosmina sp. were occasionally present. No members of the Copepod group (Crustaceans) were found.

Figure 2 presents photos of the zooplankton organisms registered in the uranium mine pit lake, with the respective body size measurements. The literature lacks information regarding the body size of organisms occurring in acidic pit lakes, and such information could be important, as well as other taxonomic features, such as dimensions, shape, and color of the zooplankton that colonized the pit lake. Figure 2e shows possible cell shrinkage in the postabdomen region, observed in a specimen from the acidic pit lake.

Table 1 Minimum and maximum values found for the physical and chemical variables in acidic pit lakes with AMD: hydrogen potential $(\mathrm{pH})$, electrical conductivity, fluoride, sulfate, aluminum, total

\section{Discussion}

The water samples from the uranium mine pit lake presented moderately acidic $\mathrm{pH}$ throughout the study, according to the classification proposed by Nixdorf et al. (2005) for acidic pit lakes. With respect to EC, a high average value $(2391 \mu \mathrm{S} / \mathrm{cm})$ was recorded for the Osamu Utsumi samples when compared to values found in German mining lakes (Table 1). In pit lakes, EC values can exceed $5000 \mu \mathrm{S} / \mathrm{cm}$, as observed by Lessmann et al. (1999) in a German pit lake, where EC values ranged from 3320 to $5840 \mu \mathrm{S} / \mathrm{cm}$.

High values of $\mathrm{Al}, \mathrm{Mn}$, and $\mathrm{Zn}$ were present in the lake. According to Friese and Schultze (2013), Al, Fe, and Mn are typically the dominant dissolved metals in acidic pit lakes due to the increased solubility of the minerals containing these elements. The mean concentrations recorded for total nitrogen and total phosphorus were 752.5 and $11.8 \mu \mathrm{g} / \mathrm{L}$, respectively. Mine lakes are very poor in phosphorus (Nixdorf et al. 2003), and total nitrogen content is much greater than total phosphorus, as observed in this study. The ranges of total nitrogen and total phosphorus observed are indicative of an oligo-mesotrophic environment (Carlson 1977).

One of the negative effects of AMD is reduced richness and diversity of aquatic species and replacement of intolerant by tolerant species (Lessmann et al. 1999; Luís et al. 2009; Nixdorf et al. 1998; Van Damme, et al. 2008; Wollmann et al. 2000). Acidic pit lakes are considered

nitrogen, total phosphorus and total metals: total iron, manganese, zinc, uranium and thorium

\begin{tabular}{|c|c|c|c|c|c|}
\hline & Lake Plessa $107^{a}$ & Lake ML $111^{2}$ & Lake ML $117^{\mathrm{b}}$ & Lake ML Felix $^{b}$ & $\begin{array}{l}\text { Osamu Utsumi } \\
\text { pit lake }(n=4)^{c}\end{array}$ \\
\hline $\mathrm{pH}$ & $2.1-2.5$ & $2.6-2.9$ & $2.8-3.0$ & $3.4-3.8$ & $3.6-4.1$ \\
\hline $\mathrm{EC}(\mu \mathrm{S} / \mathrm{cm})$ & $3320-5840$ & $2000-2800$ & 1300 & $400-520$ & $1976-2760$ \\
\hline $\mathrm{F}^{-}(\mathrm{mg} / \mathrm{L})$ & - & - & - & - & $33.4-75.1$ \\
\hline $\mathrm{SO}_{4}{ }^{2-}(\mathrm{mg} / \mathrm{L})$ & $808-4440$ & $1100-1800$ & 400 & $150-500$ & $366.6-1832$ \\
\hline $\mathrm{Al}(\mathrm{mg} / \mathrm{L})$ & $22-60$ & 35 & 1.9 & $1.8-3.8$ & $68.3-106.5$ \\
\hline Total Fe (mg/L) & $390-670$ & $130-200$ & 20 & $0.4-5.0$ & $1.76-10.8$ \\
\hline $\mathrm{Mn}(\mathrm{mg} / \mathrm{L})$ & $1.3-43.5$ & - & - & - & $71.5-143.0$ \\
\hline $\mathrm{Zn}(\mathrm{mg} / \mathrm{L})$ & $1.69-2.91$ & - & - & - & $10.8-19.9$ \\
\hline $\mathrm{U}(\mathrm{mg} / \mathrm{L})$ & - & - & - & - & $0.1-4.2$ \\
\hline $\mathrm{Th}(\mathrm{mg} / \mathrm{L})$ & - & - & - & - & $0.1-0.3$ \\
\hline Total P $(\mu \mathrm{g} / \mathrm{L})$ & $5-26$ & $<5-7$ & $5-7$ & $<5-7$ & $5.6-18$ \\
\hline Total N $(\mu \mathrm{g} / \mathrm{L})$ & - & $3.1-11.3$ & $1.9-2.3$ & $1-5$ & $700-840$ \\
\hline
\end{tabular}

a Lessmann et al. (1999)

b Wollmann et al. (2000)

c Four samples 
Table 2 Species composition of zooplankton communities found in acidic pit lakes with AMD

\begin{tabular}{|c|c|c|c|c|c|}
\hline & $\begin{array}{l}\text { Lake Plessa } \\
107^{\mathrm{a}}\end{array}$ & $\begin{array}{l}\text { Lake ML } \\
111^{\mathrm{b}}\end{array}$ & $\begin{array}{l}\text { Lake ML } \\
117^{\mathrm{b}}\end{array}$ & $\begin{array}{l}\text { Lake ML } \\
\text { Felix }^{\mathrm{b}}\end{array}$ & $\begin{array}{l}\text { Osamu Utsumi } \\
\text { pit lake }(\mathrm{n}=4)^{\mathrm{c}}\end{array}$ \\
\hline \multicolumn{6}{|l|}{ Rotifera } \\
\hline Order Bdelloidea & & & & & $\mathrm{X}$ \\
\hline Rotaria rotatoria (Pallas, 1766) & $\mathrm{X}$ & $\mathrm{X}$ & $X$ & $\mathrm{X}$ & \\
\hline Brachionus sericus Rousselet, 1907 & & & $X$ & $X$ & \\
\hline Cephalodella sp. & & & & & $\mathrm{X}$ \\
\hline Cephalodella hoodii (Gosse, 1886) & $X$ & $\mathrm{X}$ & $\mathrm{X}$ & $\mathrm{X}$ & \\
\hline Cephalodella gibba (Ehrenberg, 1830) & & & $X$ & $\mathrm{X}$ & \\
\hline Elosa worrallii Lord, 1891 & & $\mathrm{X}$ & $\mathrm{X}$ & $\mathrm{X}$ & \\
\hline Lecane lunaris (Ehrenberg, 1832) & & & & $\mathrm{X}$ & \\
\hline Lecane stichaea Harring, 1913 & & & & $\mathrm{X}$ & \\
\hline Lepadella sp. & & & $\mathrm{X}$ & $\mathrm{X}$ & \\
\hline Keratella americana Carlin, 1943 & & & & & $\mathrm{X}$ \\
\hline Keratella cochlearis (Gosse, 1851) & & & & & $\mathrm{X}$ \\
\hline Trichocerca similis (Wierzejski, 1893) & & & & $X$ & \\
\hline \multicolumn{6}{|l|}{ Cladocera } \\
\hline Chydorus sphaericus (Müller, 1785) & & & $\mathrm{X}$ & $\mathrm{X}$ & \\
\hline Bosminopsis deitersi Richard, 1895 & & & & & $\mathrm{X}$ \\
\hline Bosmina sp. & & & & & $\mathrm{X}$ \\
\hline \multicolumn{6}{|l|}{ Copepoda } \\
\hline Diacyclops sp. & & & & $\mathrm{X}$ & \\
\hline Number of species & 2 & 3 & 7 & 11 & 6 \\
\hline
\end{tabular}

harsh environments for zooplankton organisms (Nixdorf et al. 1998). In pit lakes with extremely low $\mathrm{pH}$, the relative importance of rotifers within the zooplankton community increases since the small littoral or benthic rotifers dominate over zooplankton crustaceans (Belyaeva and Deneke 2013; Deneke 2000; Wollmann et al. 2000). This was also found in this study, since the Rotifera phylum was found in significantly higher densities $\left(18,333-115,019 \mathrm{ind} / \mathrm{m}^{3}\right)$ and number of species (4) compared to the zooplankton crustacean species, which were present at densities ranging from 258 to $3113 \mathrm{ind} / \mathrm{m}^{3}$, with only two species.

Studies in acidic pit lakes (pH ranging from 2.6 to 3.8 ) formed by coal mining in Germany (Deneke 2000; Lessmann et al. 1999; Nixdorf et al. 1998; Wollmann et al. 2000), lignite mining in Australia (Moser and Weisse 2011), and pyrite exploration in the Czech Republic (Hrdinka et al. 2013) also found that the zooplankton communities of these lakes were composed mainly of rotifers common to such environments, namely Brachionus sericus, Cephalodella sp., C. gibba, C. hoodii, Elosa worrallii, Polyarthra sp., and Rotaria rotatoria (Bdelloidea order), in addition to Cladocera Chydorus sphaericus. The latter were only found in lakes where the $\mathrm{pH}$ was slightly below three. In the present study, out of the species cited above, only the rotifers of the Bdelloidea order and the Cephalodella genus were registered. On the other hand, the Rotifera Keratella americana, $K$. cochlearis, and the Cladocera Bosminopsis deitersi and Bosmina sp., are being reported for the first time in samples from a uranium mine pit lake with AMD, indicating the capacity of these zooplankton organisms to colonize extreme environments, despite ionizing radiation, low $\mathrm{pH}$, and multiple chemical stressors.

In a study conducted on an oligo-mesotrophic dam (Bortolan) not impacted by AMD and at a $30 \mathrm{~km}$ distance from the uranium mine pit lake, Ferrari (2010) recorded a higher diversity of zooplanctonic species (43), than the number recorded in this study (6). Among the species registered at Bortolam dam, Keratella americana, $K$. cochlearis, order Bdelloideia, Bosminopsis deitersi, and Bosmina sp. were also found in our pit lake samples. On the other hand, that study did not detect the Cephalodella sp. that were found in this lake. Our findings corroborate the results obtained by Jersabek et al. (2011) in Austria and Germany and Deneke (2000) in Europe and North America, respectively, who found that Cephalodella acidophila sp, $C$. gibba, and $C$. hoodii were characteristic of acidic pit lakes. 

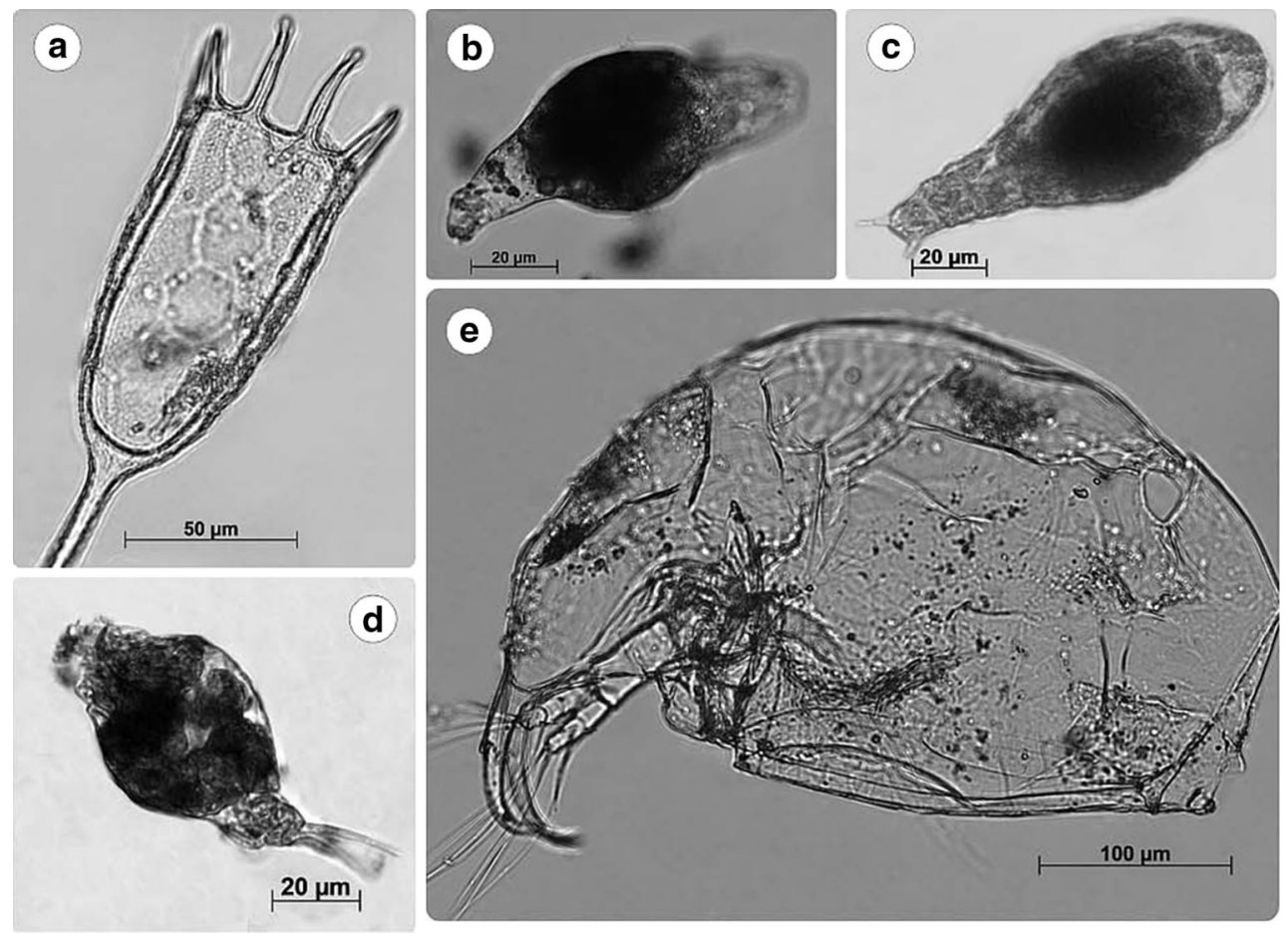

Fig. 2 Light microscope view ( $\times 10-40$ magnification) of the identified Rotifera (a Keratella americana; b, c: order Bdelloidea-contracted body; d Cephalodella sp.) and Cladocera (e Bosmina sp.), in water samples from the uranium mine pit lake

Since the species registered in this study are not restricted to acid $\mathrm{pH}$ environments, they can be considered as more generalized. Moreover, they probably persisted due to their high physiological tolerance to severe acidic stress, in addition to the absence of more efficient prey-i.e. large-bodied zooplankton crustaceans (copepods, cladocerans) and planktivorous fish. According to Arnott and Vanni (1993) and Belyaeva and Deneke (2013), the water chemistry in acidic pit lakes notably influences the composition of the species in these habitats, since the pressure of the biotic factors (predators and competition) decreases at low $\mathrm{pH}$. In acidic water, the organisms must maintain a circumneutral $\mathrm{pH}$ in the cytoplasm (Weithoff 2005). According to Havens (1993), the extinction of larger-bodied zooplankton might be due to the acid stress caused by the $\mathrm{H}^{+}$concentration and the toxic stress of metals that can impair the normal process of osmoregulation in acid-sensitive zooplankton.

In the Osamu Utsumi pit lake, an acidic and oligo-mesotrophic environment, both Keratella americana and $K$. cochlearis were registered. $K$. cochlearis is a very common cosmopolitan rotifer species, typically found in this kind of environment (Turner 1987; Xi et al. 2002) and acidic freshwater (Koste 1978). In a study carried out in an acid lake formed by uranium mining activities in the Harrison Peninsula, Canada, Kalin et al. (2001) registered the occasional occurrence of low densities $\left(0.008-0.016 \mathrm{ind} / \mathrm{m}^{3}\right)$ of Kerattela sp. In our samples, $K$. americana and $K$. cochlearis were registered with greater densities (575 and $833 \mathrm{ind} / \mathrm{m}^{3}$ ), respectively, than those registered by Kalin et al. (2001).

Cephalodella sp., with body sizes ranging from 86 to $98 \mu \mathrm{m}$, was registered in this study. Recently, a new species of Cephalodella, C. acidophila sp., was observed in two extremely acidic mine lakes $(\mathrm{pH}<3)$ in Austria and Germany (Jersabek et al. 2011), while $C$. hoodii and $C$. gibba were described in studies in highly acidic mine lakes in Europe and North America (Deneke 2000). According to Viayev (2010), Cephalodella shows a wide range of environmental preference, which could explain the occurrence of C. acidophila, C. gibba, and C. hoodii in extremely acidic pit lakes. Nogrady and Pourriot (1995) consider Cephalodella one of the most taxonomically difficult genus amongst all rotifers, due to the great similarity of the phenotypes and the large number (190) of species in this genus.

In Lake Plessa-107, a coal mine lake in Germany, Lessmann et al. (1999) only found the rotifers Cephalodella hoodii and Rotaria rotatoria (Bdelloidea order) at extremely acid $\mathrm{pH}$ values (2.1-2.3) and elevated $\mathrm{Al}, \mathrm{Mn}$, and $\mathrm{Zn}$. In contrast, samples from this study in moderately acid $\mathrm{pH}$ values (3.6-4.1) contained six zooplankton species, including the Rotifera Cephalodella sp. and Bdelloidea. 
Wollmann et al. (2000) found that $\mathrm{pH}$ was the most important variable governing the richness of the zooplankton species in the mine lakes ML-111 ( $\mathrm{pH} 2.6-2.9)$, ML-117 (pH 2.8-3.0), and ML-Felix (pH 3.4-3.8), with 3, 7 , and 11 species, respectively. Results from this study indicate that $\mathrm{pH}(3.6-4.1)$ were in the same range as Lake ML-Felix, but with fewer (6) zooplankton species. Rotifers are the most $\mathrm{pH}$ tolerant taxa of zooplankton (Nixdorf et al. 2005), surviving in extremely acidic waters ( $\mathrm{pH}<2.8$ ), besides being the least sensitive to metals (Jak et al. 1996).

Our investigation demonstrated that the rotifers were the most representative organisms in terms of density $\left(17,500-77,778 \mathrm{ind} / \mathrm{m}^{3}\right)$ throughout the study. According to Gladyshev and Meselson (2008), rotifers of the order Bdelloidea are extremely resistant to ionizing radiation (IR), with greater resistance and adaptation with respect to IR than other zooplankton. The ability of the Bdelloids to remain fertile after extensive DNA breakage and other damage caused by exposure to IR reflects their evolutional adaptation, attributed to their damage repair capability or to repair protection systems, or both (Gladyshev and Meselson 2008). Raised levels of radioactivity and high concentrations of radionuclides have been detected in the Osamu Utsumi pit lake (Gomes et al. 2002; Silva et al. 2000; Veiga et al. 2000). Sheppard et al. (2005), through eco-toxicological tests applied to some freshwater invertebrates, defined that the predicted no-effect concentration (PNEC) for chemical toxicity of uranium to these organisms is $0.005 \mathrm{mg} / \mathrm{L}$ of $U$. Thus, the $U$ concentrations in the lake $(0.1-4.2 \mathrm{mg} / \mathrm{L})$ could explain the higher density values of Bdelloidea.

Among the zooplanktonic cladocerans, the density of Bosminopsis deitersi and Bosmina sp. was low. B. deitersi is a tropical cladoceran species that has been commonly recorded in Brazilian freshwaters (Melão and Rocha 2006; Nogueira 2001) and is a sensitive indicator of polluted waters (Rocha and Güntzel 1999). Therefore, the high metal concentrations and low $\mathrm{pH}$ in the Osamu Utsumi pit lake could be chronically toxic to this species (Locke and Sprules 2000). Toxicity studies conducted with cladocerans have reported that concentrations of $0.8 \mathrm{mg} / \mathrm{L}$ of $\mathrm{Mn}$ (WHO 2004) and $1 \mathrm{mg} / \mathrm{L}$ of Zn (Sanchez-Ortiz et al. 2010) can adversely affect their growth and reproduction. Sheppard et al. (2005) have proposed a PNEC of $0.005 \mathrm{mg} / \mathrm{L}$ of $\mathrm{U}$ for freshwater invertebrates. The metal values in this study were, on average, 40 times the values considered toxic to cladocerans and other freshwater invertebrates, according to the authors cited above. The effects of $U$ on the zooplankton may be due to chemical toxicity, given that the chemotoxicity of depleted uranium is much greater than its radiotoxicity (Mathews et al. 2009; Sheppard et al. 2005).
Moreover, other studies have indicated that some environmental toxicants can produce morphological abnormalities in the cladoceran Ilyocryptus spinifer (ElmoorLoureiro 2004) and Daphnia species (Zanata et al. 2008), as possibly observed here for Bosmina sp. Woelfl and Whitton (2000) quantified cellular losses and deformation during fixation of planktonic organisms from acidic environments, and reported that taxonomic determination of acidic water organisms is often difficult since traditional taxonomic features such as dimensions, shape and colors may be hard to recognize reliably. According to ElmoorLoureiro (2004), bioassays should be conducted to test the hypothesis of environmentally-induced abnormalities in zooplankton and to verify the responsible substances.

\section{Conclusion}

It is clear that potential stressors (moderately acidic $\mathrm{pH}$ and high concentrations of stable and radioactive contaminants) could have influenced the richness and composition of the zooplankton community in this uranium mine pit lake. However, specific causes cannot be established, but only inferred. This suggests that laboratory studies, including toxicity tests, should be carried out to assess the toxic effects caused by each isolated chemical stressor and their combined action in different $\mathrm{pH}$ variations. Such tests could be important in evaluating each species' ecological behavior, especially with respect to potentially toxic elements, including the stable $(\mathrm{Mn}, \mathrm{Al}$, and $\mathrm{Zn})$ and radioactive (U) chemical species found in anomalous concentrations in this pit lake.

Acknowledgments This study was funded by the State of Minas Gerais Research Aid Foundation (FAPEMIG APQ-7807-5.04/07). We also thank AL Bruschi, MB Campos, HLA Caponi, EO Lima, and LB Ronqui for their technical support.

\section{References}

Antunes SC, Figueiredo D, Marques RS, Castro BB, Pereira R, Gonçalves F (2007) Evaluation of water column and sediment toxicity from abandoned uranium mine using a battery of bioassays. Sci Total Environ 374:252-259

APHA (American Public Health Assoc) (1995) Standard Methods for the Examination of Water and Wastewater, 19th edn. American Public Health Assoc, American Water Works Assoc, Water Environment Federation, Washington

Arnott SE, Vanni MJ (1993) Zooplankton assemblages in fishless bog lakes: influence of biotic and abiotic factors. Ecology 74:2361-2380

ASTM (American Society for Testing and Materials) (1980) Annual Book of ASTM standards. PA, USA, Philadelphia

Ayres M, Ayres MJr, Ayres DL, Santos AS (2005) BioEstat 2.0: Aplicações estatísticas na área das Ciências Biológicas e Médicas. Mamirauá, Editora Gráfica Ltda 
Batty LC (2005) The potential importance of mine sites for biodiversity. Mine Water Environ 24(2):101-103

Belyaeva M, Deneke R (2007) Colonization of acidic mining lakes: Cydorus sphaericus and other Cladocera within a dynamic horizontal $\mathrm{pH}$ gradient $(\mathrm{pH}$ 3-7) in Lake Senftenberger See (Germany). Hydrobiologia 594:97-108

Belyaeva M, Deneke R (2013) The biology and ecosystems of acidic pit lakes. Zooplankton. In: Geller W, Schultze M, Kleinmann R, Wolkersdorfer C (eds) acidic pit lakes. Springer, Berlin, pp 117-126. doi:10.1007/978-3-642-29384-9

Campos MB, Azevedo H, Nascimento MRL, Roque CV, Rodgher S (2011) Environmental assessment of water from a uranium mine (Caldas, Minas Gerais State, Brazil) in a descommissioning operation. Environ Earth Sci 62:857-863

Carlson RE (1977) A trophic state index for lakes. Limnol Oceanogr 22:361-369

Ciszewski D, Aleksander-Kwaterczak U, Pociecha A, Szarek-Gwiazda E (2013) Small effects of a large sediment contamination with heavy metals on aquatic organisms in the vicinity of an abandoned lead and zinc mine. Environ Monit Assess 185:9825-9842

De-Melo R, Hebert PDN (1994) A taxonomic reevaluation of North American Bosminidae. Can J Zool 72:1808-1825

Deneke R (2000) Review of rotifers and crustacean in highly acidic environments of $\mathrm{pH}$ values $\leq 3$. Hydrobiologia 433:167-172

Durán AP, Rauch J, Gaston K (2013) Global spatial coincidence between protected areas and metal mining activities. Biolog Conserv 160:272-278

Eary LE, Castendyk DN (2013) Hardrock metal mine pit lakes: occurrence and geochemical characteristics. In: Geller W, Schultze M, Kleinmann R, Wolkersdorfer C (eds) Acidic Pit Lakes. Springer, Berlin, pp 75-106. doi:10.1007/978-3-642-29384-9

Elmoor-Loureiro LMA (1997) Manual de Identificação de Cladóceros Límnicos do Brasil. Universa, Brasília, Brazil

Elmoor-Loureiro LMA (2004) Morphological abnormalities in the cladoceran Ilyocryptus spinifer (Apipucos reservoir, Pernambuco State, Brazil). Braz J Biol 64:53-58

Ferrari CR (2010) Avaliação de efeitos de efluentes radioativos de mineração de urânio sobre características físicas, químicas e diversidade da comunidade zooplanctônica na Unidade de Tratamento de Minérios, na Represa das Antas e Represa Bortolan, Poços de Caldas (MG). Dissertação. Universidade de São Paulo, Brazil

Friese K, Herzsprung P, Schultze M (2013) Limnochemistry of water and sediments of acidic pit lakes pit lakes from coal and lignite mining. In: Geller W, Schultze M, Kleinmann R, Wolkersdorfer C (eds) acidic pit lakes. Springer, Berlin, pp 42-57. doi:10.1007/ 978-3-642-29384-9

Fukuma HT, De Nadai Fernandes EA, Nascimento MRL, Quinelato AL (2001) Separation and spectrophotometric determination of thorium contained in uranium concentrates. J Radioanal Nucl Ch 248:533-549

Gladyshev E, Meselson M (2008) Extreme resistance of bdelloid rotifers to ionizing radiation. $P$ Natl Acad Sci USA 105:5139-5144

Golterman HL, Clymo RS, Ohnstad MAM (1978) Methods for Physical and Chemical Analysis of Freshwaters, 2nd edn. Blackwell Scientific Publications, Oxford

Gomes HA, Nouailhetas Y, Silva NC, Mezrahi A, Almeida CEB, Rodrigues GS (2002) Biological response of Tradescantia stamen-hairs to high levels of natural radiation in the Poços de Caldas plateau. Braz Arch Biol Technol 45:301-307

Havens KE (1993) Acid and aluminum effects on osmoregulation and survival of the freshwater copepod Skistodiaptomus oregonensis. J Plankton Res 15:683-691
Holopainen IJ, Holopainen AL, Hämäläinen H, Rahkola-Sorsa M, Tkatcheva V, Viljanen M (2003) Effects of mining industry waste waters on a shallow lake ecosystem in Karelia, north-west Russia. Hydrobiologia 506-509(1-3):111-119

Hrdinka T, Sobr M, Fott J, Nedbalova L (2013) The unique environment of the most acidified permanently meromictic lake in the Czech Republic. Limnologica 43:417-426

Jak RG, Maas JL, Scholten MCT (1996) Evaluation of laboratory derived toxic effect concentrations of a mixture of metals by testing freshwater plankton communities in enclosures. Water Res 30:1215-1227

Jersabek CD, Weithoff G, Weisse T (2011) Cephalodella acidophila n. sp. (Monogononta: Nommatidae), a new rotifer species from highly acidic mining lakes. Zootaxa 2939:50-58

Kalin M, Cao Y, Smith M, Olaveson M (2001) Development of the phytoplankton community in a pit-lake in relation to water quality changes. Water Res 35:3215-3225

Koste W (1978) Rotatoria Die Rädertiere Mitteleuropas. Überordnung Monogononta, Gebrüder Borntraeger, Berlin

Kotov AA, Ishida S, Taylor DJ (2009) Revision of the genus Bosmina Baird 1845 (Cladocera: Bosminidae), based on evidence from male morphological characters and molecular phylogenies. Zool J Linn Soc Lond 156:1-51

Lefcort H, Vancura J, Lider EL (2010) 75 Years after mining ends stream insect diversity is still affected by heavy metals. Ecotoxicology 19:1416-1425

Lessmann D, Deneke R, Ender R, Hemm M, Kapfer M, Krumbeck H, Wollmann K, Nixdorf B (1999) Lake Plessa 107 (Lusatia, Germany) an extremely acidic shallow mining lake. Hydrobiologia 408(409):293-299

Locke A, Sprules WG (2000) Effects of acidic pH and phytoplankton on survival and condition of Bosmina longirostris and Daphnia pulex. Hydrobiologia 437:187-196

Luís AP, Teixeira P, Almeida SFP, Ector L, Matos JX, Ferreira da Silva EA (2009) Impact of acid mine drainage (AMD) on water quality, stream sediments and periphytic diatom communities in the surrounding stream of Aljustrel mining area (Portugal). Water Air Soil Pollut 200:147-167

Lyew D, Sheppard JD (1997) Effects of physical parameters of a gravel bed on the activity of sulphate-reducing Bacteria in the presence of acid mine drainage. J Chem Technol Biotechnol 70:223-230

Lyew D, Sheppard JD (2001) Use of conductivity to monitor the treatment of acid mine drainage by sulphate-reducing Bacteria. Water Res 35:2081-2086

Mathews T, Beaugelin-Seiller K, Garnier-Laplace J, Gilbin R, Adam C, Della-Vedova C (2009) A probabilistic assessment of the chemical and radiologicalrisks of chronic exposure to uranium in freshwater ecosystems. Environ Sci Technol 43:6684-6690

Melão MGG, Rocha O (2006) Life history, population dynamics, standing biomass and production of Bosminopsis deitersi (Cladocera) in a shallow tropical reservoir. Acta Limnol Bras 18(4):433-450

Moser M, Weisse T (2011) The most acidified Austrian lake in comparison to a neutralized mining lake. Limnologica 41:303-315

Nascimento MRL, Fukuma HT, Hortellani MA (1988) Projeto Itataia-Controle de processo na produção de ácidos fosfórico e urânio. Poços de Caldas: INB, (Manual de Métodos e Análises Químicas), Brazil

Nixdorf B, Wollmann K, Deneke R (1998) Ecological potentials for planktonic development and food web interactions in extremely acidic mining lakes in Lusatia. In: Geller W, Klapper H, Salomons W (eds) Acidic mining lakes. Springer, Berlin, pp 147-167. doi:10.1007/978-3-642-71954-7_8 
Nixdorf B, Krumbeck H, Jander J, Beulker C (2003) Comparison of bacterial and phytoplankton productivity in extremely acidic mining lakes and eutrophic hard waters lakes. Acta Oecol 24:S281-S288

Nixdorf B, Lessmann D, Deneke R (2005) Mining lakes in a disturbed landscape: application of the EC Water Framework Directive and future management strategies. Ecol Eng 24:67-73

Nóbrega FA, Lima HM, Leite AL (2008) Análise de múltiplas variáveis no fechamento da mina-Estudo de caso da pilha de estéril BF-4, Mina Osamu Utsumi, INB Caldas, Minas Gerais. Revista Escola de Minas Ouro Preto 61:197-202

Nogrady T, Pourriot R (1995) Rotifera: The Notommatidae. In: Nogrady T, Dumont HJ (eds) Guides to the Identification of the macroinvertebrates of the Continental Waters of the World. SPB Academic Publications, New York

Nogueira MG (2001) Zooplankton composition, dominance and abundance as indicators of environmental compartmentalization in Jurumirim Reservoir (Paranapanema River), São Paulo Brazil. Hydrobiologia 455:1-18

Riethmuller N, Markich SJR, Van Dam A, Parry D (2001) Effects of water hardness and alkalinity on the toxicity of uranium to a tropical freshwater hydra (Hydra viridissima). Biomarkers 6:43-51

Rocha O, Güntzel AM (1999) Branchiopoda, Cladocera. In: Ismael D, Valenti WC. Matsumura-Tundisi T, Rocha O (Org), Biodiversidade do estado de São Paulo, Brasil: síntese do conhecimento ao final do século XX, 4: Invertebrados de água doce. $1^{\text {st }}$, edit, Fapesp, São Paulo, Brazil, p 107-120

Rodgher S, Azevedo H, Ferrari CR, Roque CV, Roqui LB, Campos MB, Nascimento MRL (2013) Evaluation of surface water quality in aquatic bodies under the influence of uranium mining (MG, Brazil). Environ Monit Assess 185:2395-2406. doi:10. 1007/s10661-012-2719-5

Sanchez-Ortiz JR, Sarma SSS, Nandini S (2010) Comparative population growth of Ceriodaphnia dubia and Daphnia pulex (Cladocera) exposed to zinc toxicity. J Environ Sci Heal A 45(1):37-41

Saro L, Lopes Y, Chastinet CBA, Cohin-de-Pinho SJ, Moreira-Santos M, Silva EM, Ribeiro R (2011) Potential re-colonisation by cladocerans of an acidic tropical pond. Chemosphere 82:1072-1079

Sheoran AS, Sheoran V (2006) Heavy metal removal mechanism of acid mine drainage in wetlands: a critical review. Miner Eng 19:105-116

Sheppard SC, Sheppard MI, Gallerand MO, Sanipelli B (2005) Derivation of ecotoxicity thresholds for uranium. J Environ Radioact 79(1):55-83

Shiel RJ, Koste W (1992) Rotifera fron Australian inland waters. VIII. Trichocercidae (Monogononta). T Roy Soc South Aust 116:1-27

Shiel RJ, Koste W (1993) Rotifera from Australian inland waters. IX. Gastropodidae, Synchaetidae, Asplanchinidae (Rotifera Monogononta). T Roy Soc South Aust 117:111-139
Silva NC, Taddei MHT, Cipriani M, Fernandes EAN (2000) Radioactivity associated with sediments from the Pocos de Caldas Plateau - a Brazilian area of high level natural radiation. In: Poster Proceedings 5th international conference on high levels of natural radiation and radon areas: radiation dose and health effects, Munich, p 69

Soucek DJ, Cherry DS, Currie RJ, Latimer HA, Trent GC (2000) Laboratory to field validation in an integrative assessment of an acid mine drainage-impacted watershed. Environ Toxicol Chem 19:1036-1043

Soucek DJ, Cherry DS, Zipper CE (2001) Aluminum-dominated acute toxicity to the cladoceran Ceriodaphnia dubia in neutral waters downstram of an acid mine drainage discharge. Can $\mathbf{J}$ Fish Aquat Sci 58:2396-2404

Turner PN (1987) Keratella rotifers found in Brazil, and a survey of Keratella rotifers from the Neotropics. Amazoniana 2:223-236

Van Damme PA, Hammel C, Ayala A, Bervorts L (2008) Macroinvertebrate community response to acid mine drainage in rivers of the High Andes (Bolivia). Environ Pollut 156:1061-1068

Veiga LHS, Sachet I, Melo V, Magalhães MH, Amaral ECS (2000) Brazilian areas of high background radiation. Are levels really high? In: Poster Proceedings 5th international conference on high levels of natural radiation and radon areas: radiation dose and health effects, Munich, p 62

Viayev RM (2010) An overview of the rotifers of the family Nommatidae (Rotifera: Monogononta: Ploima) from Ira. Caspian J Env Sci 8:127-139

Weithoff G (2005) On the ecology of the rotifer Cephalodella hoodii from an extremely acidic lake. Freshwater Biol 50:1464-1473

Wendt-Potthoff K (2013) The biology and ecosystems of acidic pit lakes. In: Geller W, Schultze M, Kleinmann R, Wolkersdorfer C (eds) Acidic pit lakes. Springer, Berlin, p 107

Woelfl S, Whitton BA (2000) Sampling, preservation and quantification of biological samples from highly acidic environments $(\mathrm{pH} \leq 3)$. Hydrobiologia 433:173-180

Wollmann K, Deneke R, Nixdorf B, Packroff G (2000) Dynamics of planktonic food webs in three mining lakes across a pH gradient (pH 2-4). Hydrobiologia 433:3-14

World Health Organization (WHO) (2004) Manganese and its Compounds: Environmental Aspects Concise International Chemical Assessment Document 63. World Health Org, Geneva

Xi Y, Jin H, Xie P, Huang X (2002) Morphological variation of Keratella cochlearis (Rotatoria) in a shallow, eutrophic subtropical Chinese Lake. J Freshwater Ecol 17:447-454

Zanata LH, Espíndola ELG, Rocha O, Pereira RHG (2008) Morphological abnormalities in Cladocera (Branchiopoda) in a cascade of reservoirs in the middle and lower Tietê river (São Paulo, Brazil). Braz J Biol 68(3):681-682 